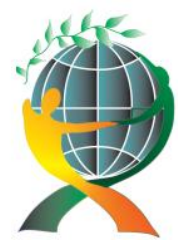

(online) $=$ ISSN $2285-3642$

ISSN-L = 2285 - 3642

Journal of Economic Development, Environment and People

Volume 1, Issue 3, 2012

URL: http://jedep.spiruharet.ro

e-mail: office jedep@spiruharet.ro

\title{
Climate Change and the Risk Management in
}

\section{Serbian Inland Waterway Transport}

\author{
Todor Backalic ${ }^{1}$, Marinko Maslaric ${ }^{2}$ \\ ${ }^{1}$ Faculty of Technical Sciences, Department of Traffic Engineering \\ Trg Dositeja Obradovica 6, Novi Sad, Serbia \\ tosa@uns.ac.rs \\ ${ }^{2}$ Faculty of Technical Sciences, Department of Traffic Engineering \\ Trg Dositeja Obradovica 6, Novi Sad, Serbia \\ marinko@uns.ac.rs
}

\begin{abstract}
Climate changes require special attention and global monitoring. Impacts on nature and industry are increasingly evident. Water transport could be the backbone of the future European combined transport system. Unfortunately, risks in water transport are perhaps an under researched area and consequently, this article outlines a rationale, why it is necessary to develop competence about risk in water transport. The development of the cargo transport in river traffic depends directly on technical-exploitative characteristics of the network of inland waterways. Research of navigational abilities of inland waterways always comes before building ships or making a transport schedule. Navigation characteristics of rivers have to be determined as precise as possible, especially from the aspect of determination the possible draught of vessels.

River transport due to their operational business and environmental conditions faced with several risks having different degrees of consequences. Current risk assessment methods for water transport just consider some dramatic events. We present a new method for the assessment of risk and vulnerability of water transport where river depth represents a crucial part. The analysis of water level changes on Serbian rivers during the last sixty years was done.
\end{abstract}

Keywords: climate change, risk management, water transport

JEL Codes: Q54, Q 25, L 95, G32 


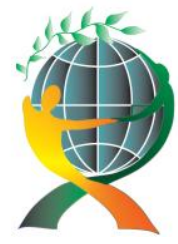

\author{
(online) $=$ ISSN $2285-3642$ \\ ISSN-L = 2285-3642 \\ Journal of Economic Development, Environment and People \\ Volume 1, Issue 3, 2012 \\ URL: http://jedep.spiruharet.ro \\ e-mail: office jedep@spiruharet.ro
}

\title{
1. Introduction
}

A logistic chain comprises all the entities and activities required to deliver final products to end customers - encompassing procurement, transportation, storage, conversation, packaging, etc. In recent years, due to increasing competition and tightening profit margins, companies have adopted a number of strategies to operate more efficiently and reduce transport and logistics costs. In general, lower cost and higher efficiencies are accomplished through a globalized logistic chain, higher capacity utilization, lower inventories, and just-in-time activities. However, there is always a trade-off between efficiency and some kind of vulnerabilities. Hence, there is a clear need for enterprises to manage logistic risks and reduce vulnerabilities so that they can respond and recover from disruptions promptly and efficiently (Arief, Rajagopalan, Iftekhar, 2009). According to this, we can conclude that risk management has become imperative for today's complex transport and logistics chain.

Inland water transport (IWT), as a crucial transport mode, could be the backbone of the future European intermodal transport chains, due to the fact that it can ship heavy as well as a large amount of commodities in combination with price advantages. Besides, inland waterways have still free shipment capacities. In Europe around 14,000 km of approximately $29,000 \mathrm{~km}$ of inland waterways are used for freight carrier. Also, IWT represents the only means of land transport which does not suffer congestion problems like that of rail or road within Europe. In general, inland waterways are underused, but inland navigation is not considered as a truly competitive alternative to other means of land transport. Estimates suggest that inland navigation would carry up to 425 million tons per year, including the accession countries, in the European inland waterway network, if the necessary action towards an integration of IWT into managed intermodal logistics chains were undertaken (European Commission, 2001).

In order to develop and implement an advanced European concept to manage intermodal transport chains with IWT as a core transport mode, we need to develop effective risk management tool for proactive management of disruptive events in IWT. Unfortunately, risk in IWT are perhaps an under researched area and consequently, this article outlines a rationale for why it is necessary to develop competence about risk and risk management in IWT. Hence, in this research we examine inland waterways logistic chains with respect to risks and accordingly disruptive events which can occur at the nodes as well as at the links of the logistic chain. The aim is to develop framework for generating an extensive risk catalogue for all associated 
logistic chain members. Briefly, risk management framework proposed in this article consists of the following
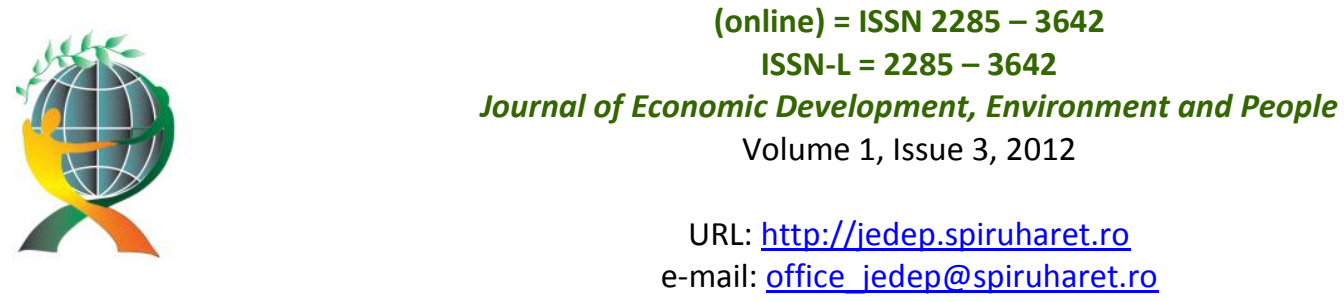

steps in sequence: risk identification, consequence analysis, risk estimation, risk mitigation, risk assessment,

and risk monitoring. This article focuses on the risk identification and risk estimation steps. In addition to that, we estimate the risk of inappropriate river depth according to their probability of occurrence and their business impact.

\section{Coping with risk in inland water transport}

There are many different definitions of risk in the literature, and we will not attempt to list them all. Some of those definitions assumed connections between risk and uncertainty, and their definition of risk is "the possibility of suffering harm or loss". From a more technical perspective, risk can be defined as the probability of an event multiplied by the (negative) consequences of the event. Kaplan (Kaplan, 1997) suggests that risk is defined by the answer to the three fundamental questions: (1) "What can go wrong?", (2) "How likely is that to happen?", and (3) "What are the consequences?". Also, risk can be defined as the potential negative impact that may arise from an adverse situation. In our context, IWT as part of intermodal logistic chain, the adverse situation is disruption to logistics operations. Disruption is defined as any event or situation that causes deviation from normal or planned logistic operations. Disruptions bring about adverse effects such as blockage of material and information flows, loss of ability to deliver the right quantity of the right product to the right place and at the right time, loss of cost efficiency, inability to meet quality requirements and process shutdown (Arief, Rajagopalan, Iftekhar, 2009). According to all above mentioned, we can conclude that risk represent exposure to circumstances with potentially damaging effects arising from an event that is not handled appropriately. So, risk is defined as product of probability of accidental event occurrence and its consequence, and risk management needs to address both sides of an accidental event, the sources leading up to it and the consequences arising from it (Sulaiman, Kader, Saharuddin, 2011).

$$
\text { Risk }(R)=\text { Probability }(P) \times \text { Consequence }(C)
$$

Risk management is the systematic approach to identifying, analyzing, and acting on risk. It incorporates all steps from the initial identification of risks to the final decision on risk-reducing actions and risk monitoring. The basic framework for risk management is illustrated in Figure 1 and follows a structure similar to (Arief, Rajagopalan, Iftekhar, 2009). The major steps are: 
1. Risk identification: The first step is to recognize uncertainties and possible sources of disruption event. A

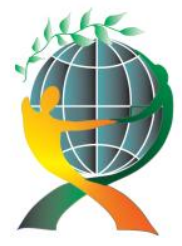

\author{
(online) $=$ ISSN $2285-3642$ \\ ISSN-L = 2285 - 3642 \\ Journal of Economic Development, Environment and People \\ Volume 1, Issue 3, 2012 \\ URL: http://jedep.spiruharet.ro \\ e-mail: office jedep@spiruharet.ro
}

wide array of methods exists for identifying sources of risk, e.g. comparative methods, fundamental methods, and logical diagram methods. Another way to identify potential risk factors is through

historical analysis, which examines historical events to gain insight into potential future risk. Nevertheless, the identification or risk sources appear to be the least-mentioned risk technique, despite the fact that it is seen as the most important step.

2. Consequence analysis: Once the risks have been identified, their consequences have to be analyzed. The disruptions due to one particular risk or a combination can be simulated and consequences propagated through the business model to identify all likely effects.

3. Risk estimation: Risk is usually quantified in financial terms and/or ranked according to some predefined criteria. Two different dimensions need to be considered: its frequency/probability and its severity/consequences, taking into account the effects of mitigating actions and safeguards, if any.

4. Risk assessment: The risk management team decides whether the risk quantified in the previous step is acceptable based on experience, industry standards, benchmarks or business targets.

5. Risk mitigation: Mitigating actions and safeguards such as emergency procedures and redundancies have to be developed, based on both the business model and inputs from the risk management team or relevant personnel.

6. Risk monitoring: the business structure and operation do not remain stationary but change regularly, for example due to changes in suppliers, regulations, operating policies, products, etc. 

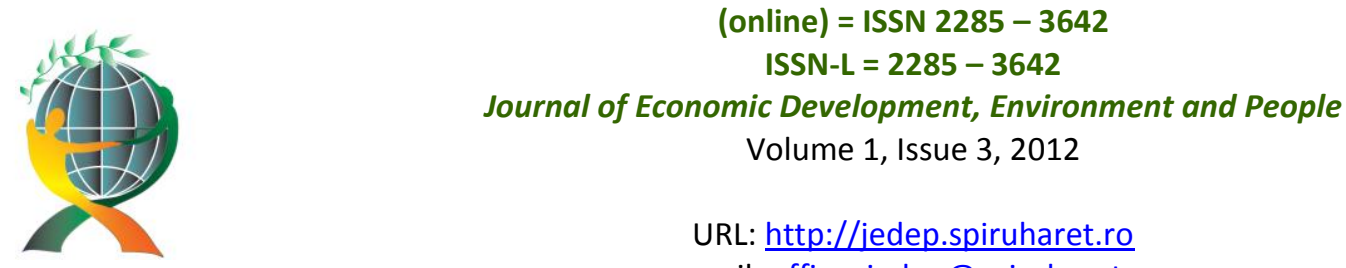

URL: http://jedep.spiruharet.ro e-mail: office jedep@spiruharet.ro

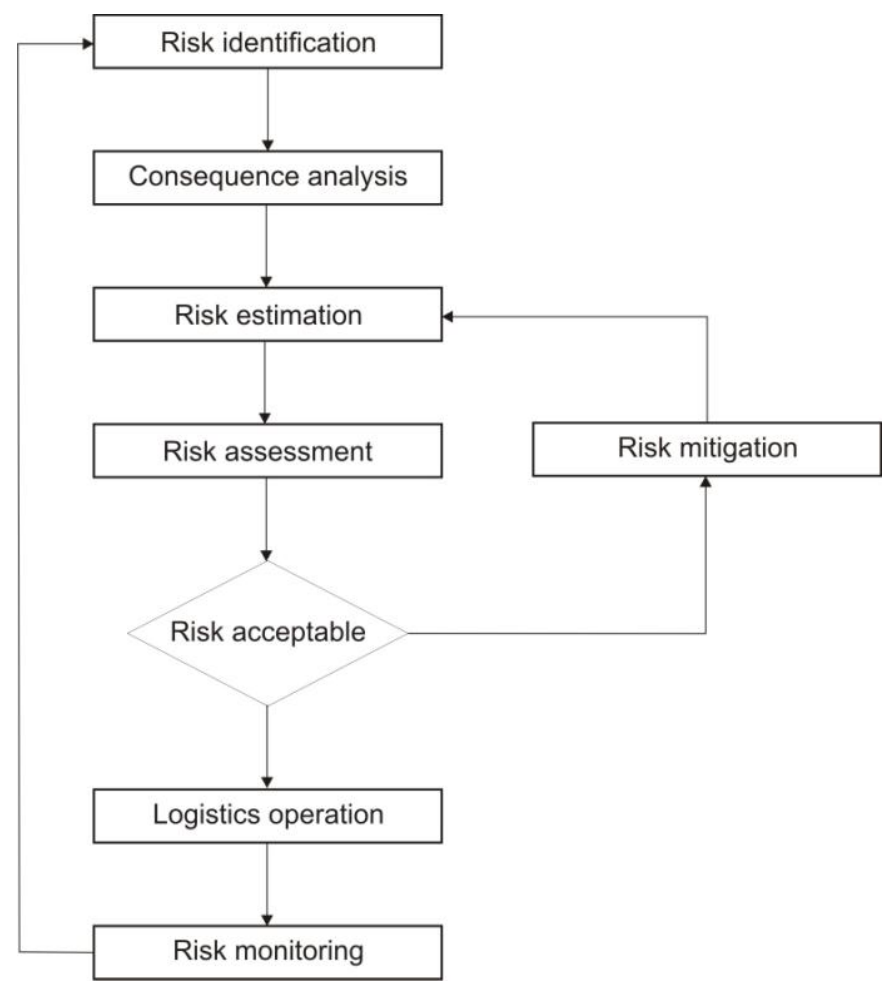

Fig.1: Basic framework for risk management

The key research question in this paper was how to engineer this basic framework for risk management in IWT in general, given the different scope of different IWT chains. That is achieved by applying the framework for categorizing logistic risk and risk management used in (Norman, Lindroth, 2004), but adapted to an IWT setting, as the Figure 2 shows. This three-dimensional approach captures the different types of risks, the managerial context and the unit of analysis along three perpendicular axes. 


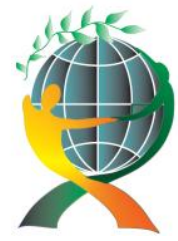

$$
\begin{gathered}
\text { (online) = ISSN } 2285-3642 \\
\text { ISSN-L = 2285 - } 3642
\end{gathered}
$$

Journal of Economic Development, Environment and People

Volume 1, Issue 3, 2012

URL: http://jedep.spiruharet.ro

e-mail: office jedep@spiruharet.ro

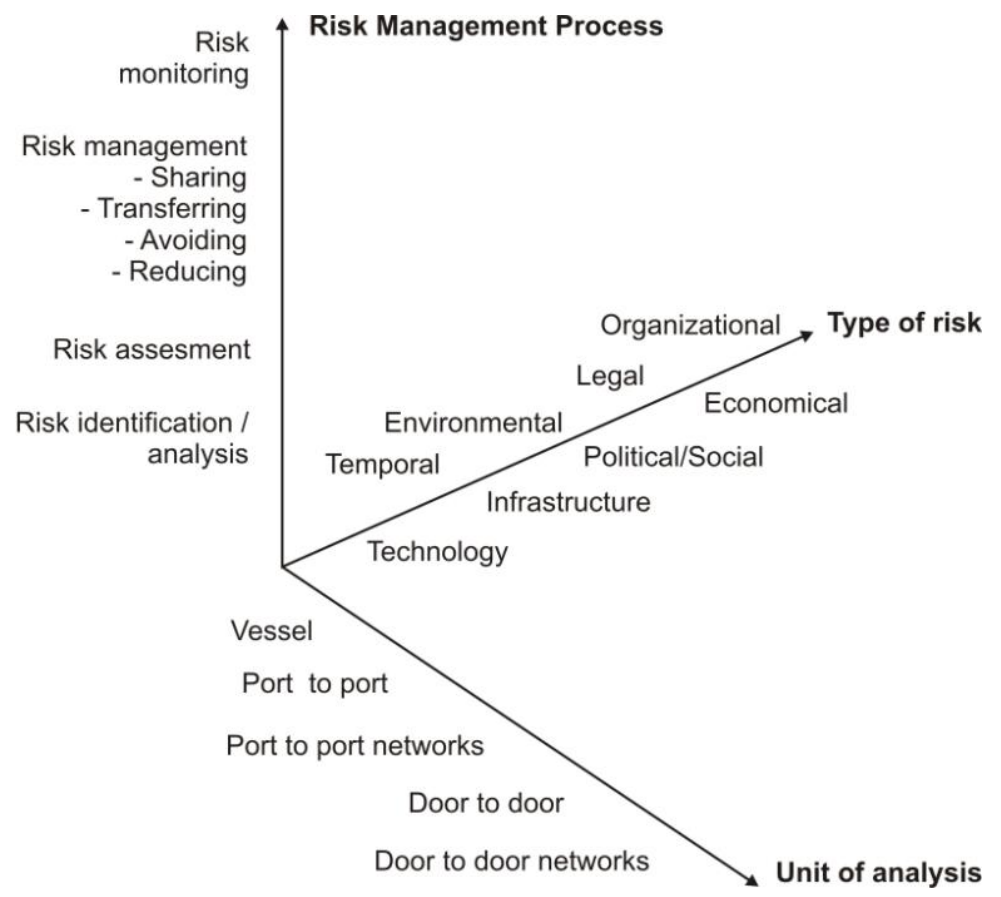

Fig. 2: The proposed framework for categorizing risk in IWT chains

In the next section we will use proposed framework for identification and estimation one kind of infrastructure risk - river depth as crucial navigation characteristics of river.

\section{River Depths and occurrence of ice as risk factors in transport process}

The river depth risk is a product of the probability of the physical event occurrence as well as losses that include damage, loss of life and economic losses. Shallow water or restricted river depth can expose vessel

owners and operators as well as the public to the possibility of vessel or cargo damage, injuries, environmental damage, etc. Complete risk modelling requires frequency estimation and consequence quantification. In the next section, based on proposed risk categorizing framework, through the appropriate case study, we will analyze frequency estimation of restricted river depth. Our case study covers only river 
depth risk, as one kind of infrastructure risks, and its identification in one part of IWT chain (unit of analysis is

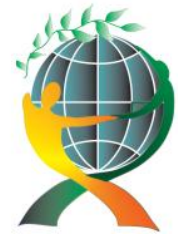

\author{
(online) $=$ ISSN $2285-3642$ \\ ISSN-L = 2285-3642 \\ Journal of Economic Development, Environment and People \\ Volume 1, Issue 3, 2012 \\ URL: http://jedep.spiruharet.ro \\ e-mail: office jedep@spiruharet.ro
}

port to port), as is shown in the Figure 3.

River depth is a variable in time and space and depends on multiple factors (climate area, basin characteristics, part of river flow, season). River depth is a variable factor with stochastic character, but it is possible to observe its seasonal disorders (Jonkeren, Rietveld, Ommeren, 2007). On all navigable rivers, there are sections with favourable and unfavourable navigational conditions. The risk analysis first determines the critical sections, i.e. river sections with the most adverse navigational characteristics. The next step is a detailed analysis of conditions and seasonal disorders. An activity flowchart of the analysis of unfavourable river depths occurrence is shown in the Figure 4.

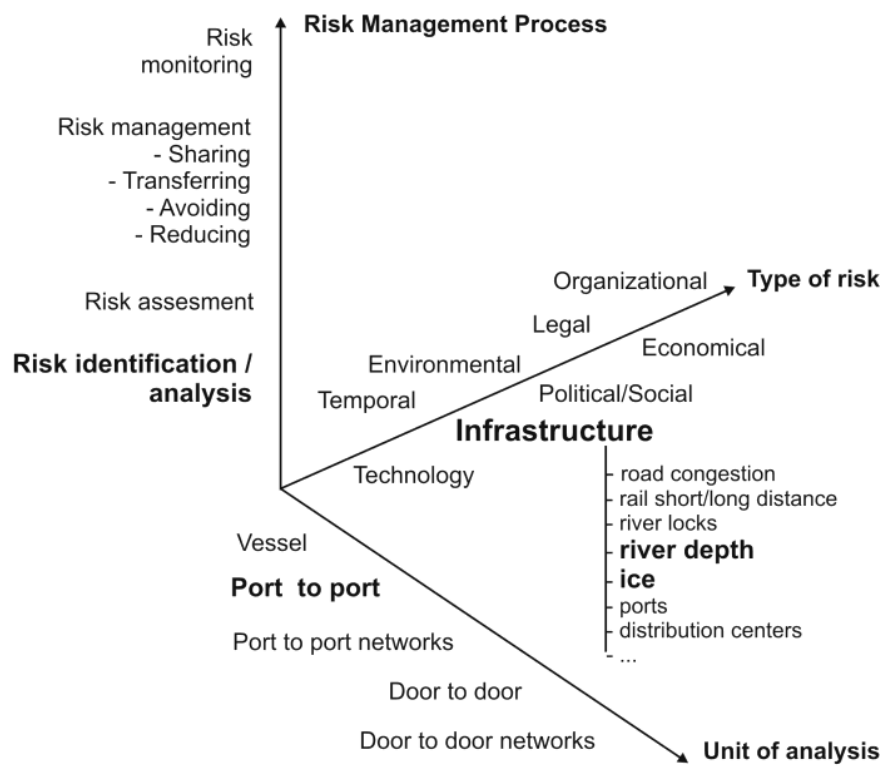

Fig. 3: Parts of the proposed framework for categorizing risk in IWT chains covered by the case study 


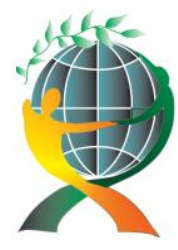

(online) $=$ ISSN $2285-3642$

ISSN-L = $2285-3642$

Journal of Economic Development, Environment and People

Volume 1, Issue 3, 2012

URL: http://jedep.spiruharet.ro

e-mail: office jedep@spiruharet.ro

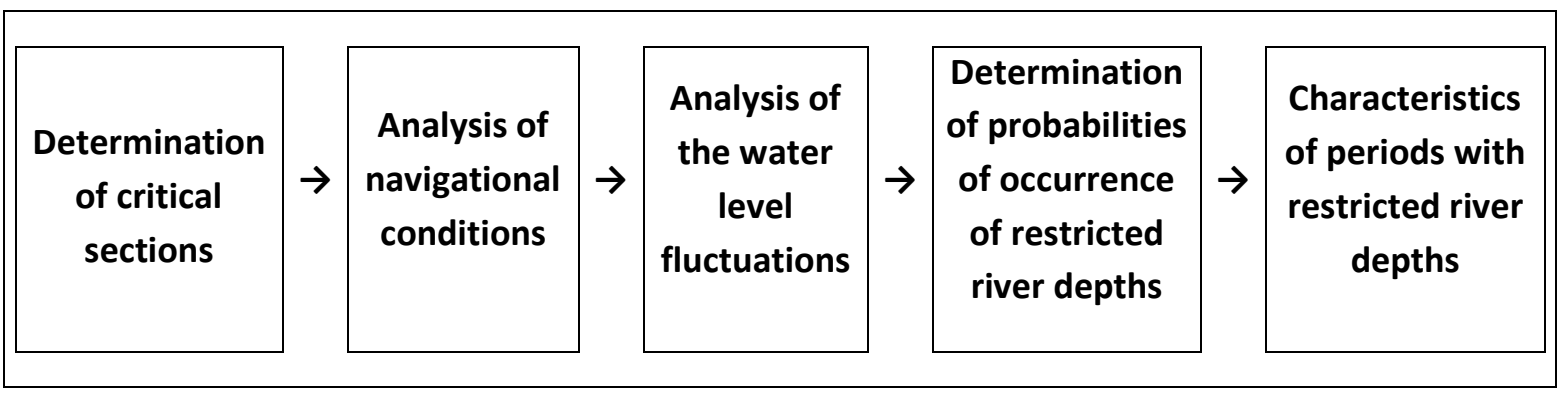

Fig. 4: Activity flowchart of the analysis of restricted river depths occurrence

Ice on river is a phenomenon that occurs solely during winter months and causes disruption in navigation. In order for ice to form on a river, the air temperature needs to be low and lasting a period of time, so flowing water freezes. An activity flowchart of the analysis of ice occurrence is shown in the Figure 5.

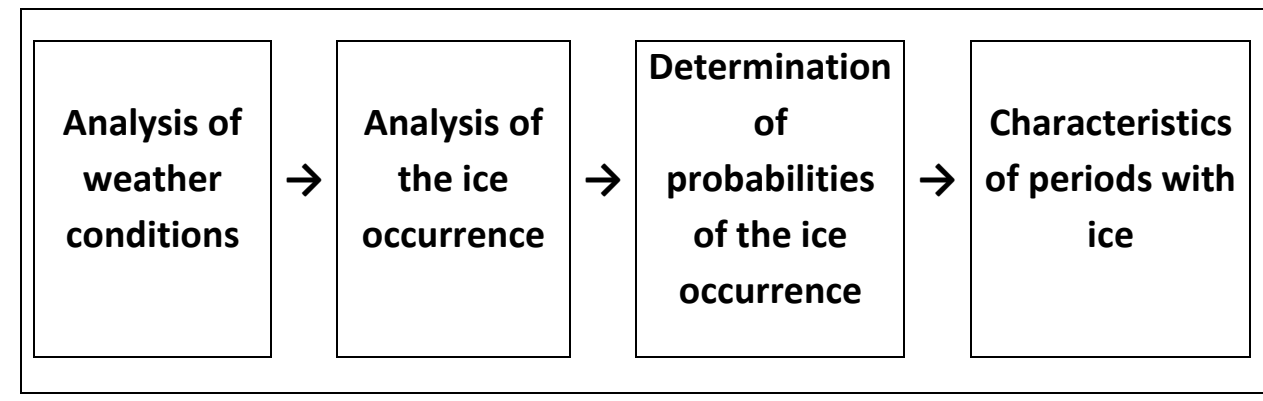

Figure 5: Activity flowchart of the analysis of ice occurrence

\subsection{Case study: analysis of restricted river depths and ice occurrence on the Danbe}

Analysis of the water level oscillation on a critical section is used to plan the navigation because low navigation levels limit the size of draught of all vessels. It is known that the size of the vessel's draught $(T)$ is usually the limiting value in project tasks and it is conditioned by the depth of the waterway or depths in certain ports. This is the reason why navigation characteristics of the Danube have to be determined as precise as possible, especially from the view point of determining in reality possible draught of vessels. (Jonkeren, Jourquin, Rietveld 2009).

Analysis of occurrence of unfavourable depths and ice on river was conducted with the goal of planning navigation period, i.e. to estimate the risk of navigation disruption due to ice. The research has been done for the period between 1 January 1958 and 31 December 2008. Duration of navigation period, i.e. 


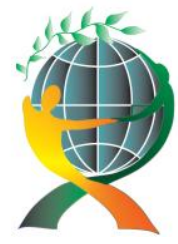

\author{
(online) $=$ ISSN $2285-3642$ \\ ISSN-L = 2285-3642 \\ Journal of Economic Development, Environment and People \\ Volume 1, Issue 3, 2012 \\ URL: $\underline{\text { http://jedep.spiruharet.ro }}$ \\ e-mail: office jedep@spiruharet.ro
}

determination of the risk of navigation disruption was based on analyses over many years and monitoring of the phenomenon trends. In order to follow the changes of a phenomenon over a period of time, the observed period was divided into three seventeen-year sections (1958-1974, 1975-1991, 1992-2008). In that way, comparison of duration, i.e. probability of occurrence in the observed segments was conducted.

\title{
3.1.1 Results of analysis for water level station Novi Sad
}

In this paper will analyze the oscillation of water level at the water level station in Novi Sad (Serbia). To get even more precise condition of waterway on this section of the Danube, during research it has been started from the assumption that the possible draught of vessels is $T=250 \mathrm{~cm}$ when water level on station Novi Sad shows $\mathrm{H}=+80 \mathrm{~cm}$ (ENR - low navigation and regulation level). That means that, at that water level, in the zone of the water meter station, navigation is possible for vessels of up to $2.5 \mathrm{~m}$ draught. It has been confirmed in practice that very often, even at water level of $+100 \mathrm{~cm}$, there are moving shoals which can cause interference and navigation disruption. For that reason, probabilities of water level occurrence that are lower than the given values were determined. (Škiljaica, Bačkalić, Škiljaica, 2009).

Basic navigation characteristics of importance for determining vessels' draughts in this period are:

- lowest navigation level determined in the observed period $(1958-2008)$ is $-29 \mathrm{~cm}$;

- highest navigation level determined in the observed period $(1958-2008)$ is $+778 \mathrm{~cm}$;

- average navigation level in the observed period (1958-2008) is $\bar{H}=251 \mathrm{~cm}$ with standard deviation from the average value $s= \pm 113 \mathrm{~cm}$, which gives an interval of possible values of navigation level $H_{\min }=+138 \mathrm{~cm}$ and $H_{\max }=+364 \mathrm{~cm}$, or draughts of vessels, average $\bar{T}=421 \mathrm{~cm}$, minimal $T_{\min }=308 \mathrm{~cm}$ and maximal $T_{\max }=534 \mathrm{~cm}$.

Based on the analysis of the observed period (1958-2008) occurrence probability of the following water levels was determined:

- lower than $+80 \mathrm{~cm}$ (ENR)

- lower than $+100 \mathrm{~cm}$ (high occurrence of banks)

- higher than $+700 \mathrm{~cm}$ (emerging flood defence)

Table 1 shows characteristic values of probability for the whole period and for parts.

Table 2 shows mutual relationships among parameters from table 2, i.e. monitoring of parameter changes over the period. 


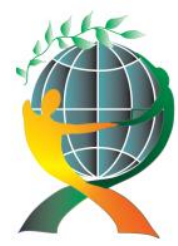

\author{
(online) $=$ ISSN $2285-3642$ \\ ISSN-L = 2285-3642 \\ Journal of Economic Development, Environment and People \\ Volume 1, Issue 3, 2012
}

URL: http://jedep.spiruharet.ro

e-mail: office jedep@spiruharet.ro

Table 1. Characteristic values of probability for the whole period and for parts

\begin{tabular}{||c|c|c|c|c||}
\hline \multirow{3}{*}{ Probability } & \multicolumn{4}{|c|}{ period } \\
\cline { 2 - 5 } & $1958-1974$ & $1975-1991$ & $1992-2008$ & $1958-2008$ \\
\cline { 2 - 5 } & $\mathrm{t}_{1}$ & $\mathrm{t}_{2}$ & $\mathrm{t}_{3}$ & $\Sigma \mathrm{t}_{\mathrm{i}}$ \\
\hline $\mathrm{P}(\mathrm{X}<80)$ & 0.1060 & 0.0754 & 0.0408 & 0.0733 \\
\hline $\mathrm{P}(\mathrm{X}<100)$ & 0.1508 & 0.1193 & 0.0846 & 0.1179 \\
\hline $\mathrm{P}(\mathrm{X}>700)$ & 0.0053 & 0.0006 & 0.0016 & 0.0025 \\
\hline
\end{tabular}

Table 2 Monitoring of parameter changes over the period

\begin{tabular}{|l|c|c|c|c|c|}
\hline \multirow{2}{*}{ Probability } & \multicolumn{5}{|c|}{$\mathrm{P}_{\mathrm{i}}$ ratio (\%) } \\
\cline { 2 - 6 } & $\mathrm{t}_{1} / \Sigma \mathrm{t}_{\mathrm{i}}$ & $\mathrm{t}_{2} / \Sigma \mathrm{t}_{\mathrm{i}}$ & $\mathrm{t}_{3} / \Sigma \mathrm{t}_{\mathrm{i}}$ & $\mathrm{t}_{3} / \mathrm{t}_{1}$ & $\mathrm{t}_{3} / \mathrm{t}_{2}$ \\
\hline $\mathrm{P}(\mathrm{X}<80)$ & +44.6 & +2.9 & -44.4 & -61.6 & -45.9 \\
\hline $\mathrm{P}(\mathrm{X}<100)$ & +28.0 & +1.2 & -28.2 & -43.9 & -29.1 \\
\hline $\mathrm{P}(\mathrm{X}>700)$ & +110.6 & -74.5 & -36.2 & -69.7 & +150.0 \\
\hline
\end{tabular}

The period between 1958 and 2008 was analyzed (51 years) and the following parameters were monitored:

- average water level trends (figure 6)

- trends of maximum water level changes by months (figure 7)

- trends of average water level changes by months (figure 7)

- trends of minimum water level changes by months (figure 7)

- trends of changes of standard deviation from average water level by months (figure 7) 


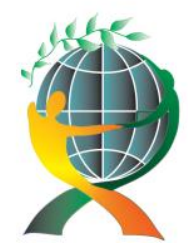

\author{
(online) $=$ ISSN $2285-3642$ \\ ISSN-L = $2285-3642$ \\ Journal of Economic Development, Environment and People \\ Volume 1, Issue 3, 2012
}

URL: http://jedep.spiruharet.ro

e-mail: office jedep@spiruharet.ro

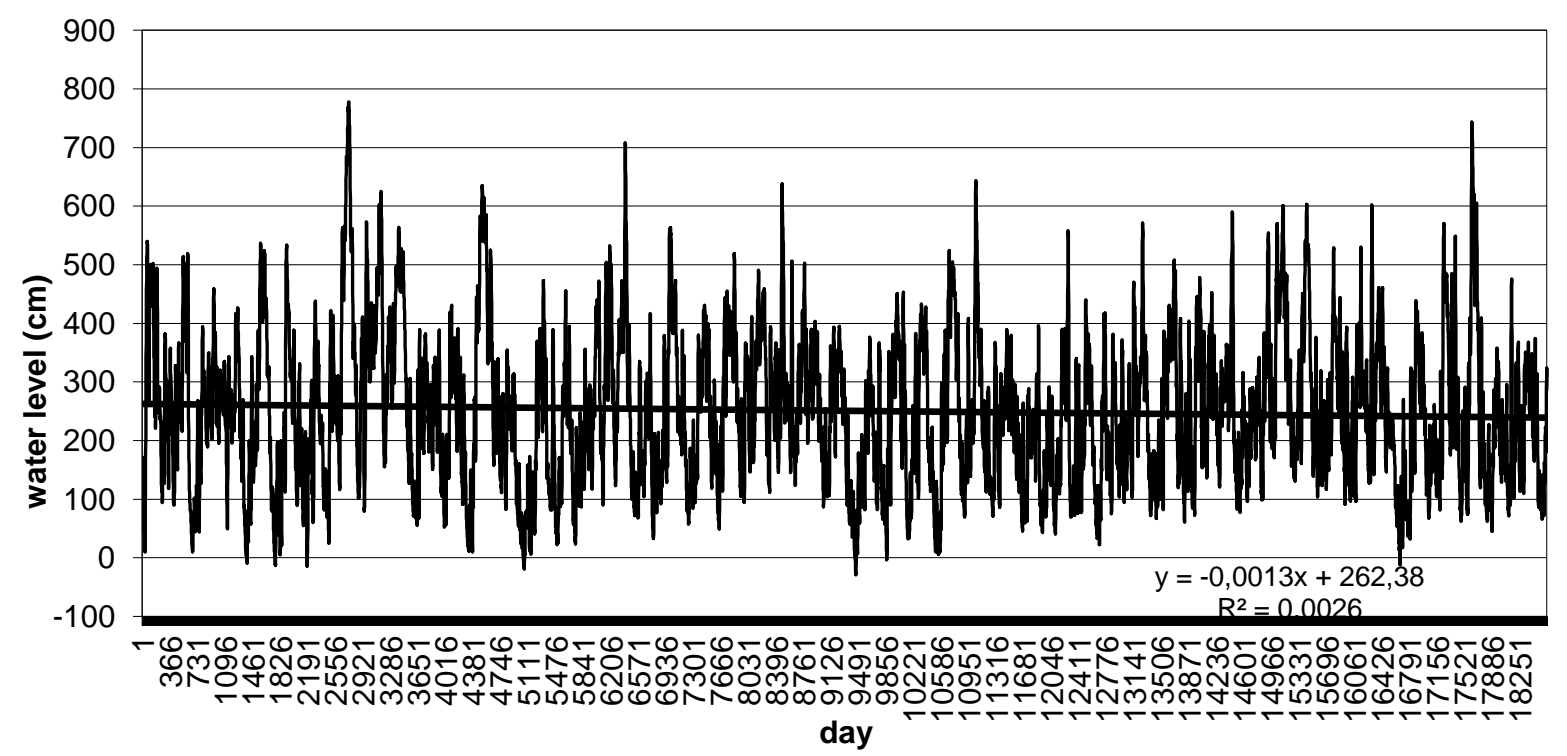

Fig. 6. Average water level trends

\title{
3.1.2 Results of analysis of ice occurrence
}

Analysis of occurrence of ice on the Danube was also conducted in the period of 1958-2008 and the following parameters were monitored:

- number of days with ice during winter (figure 8)

- probability of occurrence of days with ice (table 3)

- probability of occurrence of years with ice (table 4)

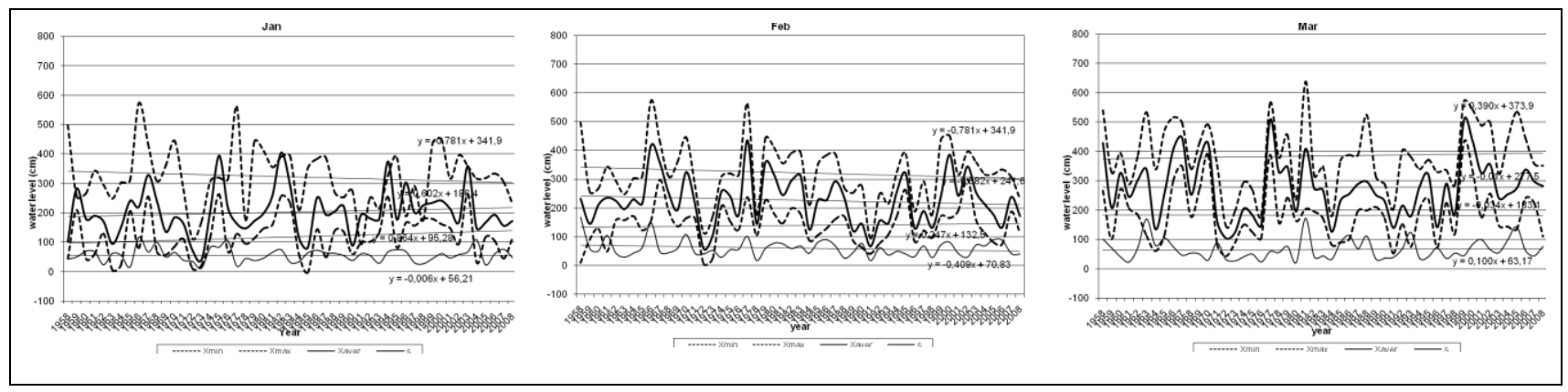




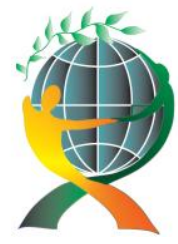

\author{
(online) $=$ ISSN $2285-3642$ \\ ISSN-L = 2285-3642 \\ Journal of Economic Development, Environment and People \\ Volume 1, Issue 3, 2012
}

URL: http://jedep.spiruharet.ro

e-mail: office jedep@spiruharet.ro

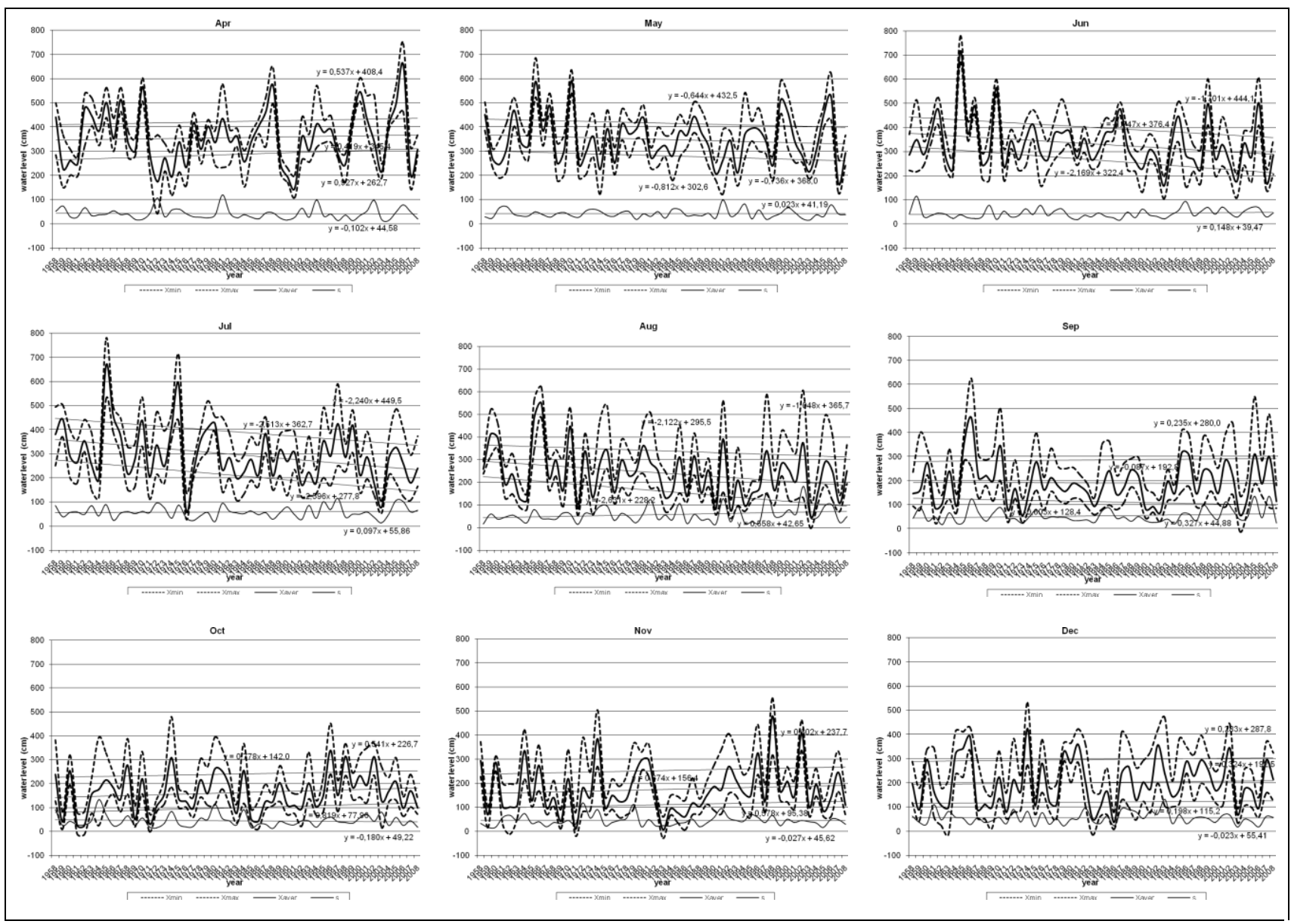

Fig. 7. Trends of changes of water level parameters by months 


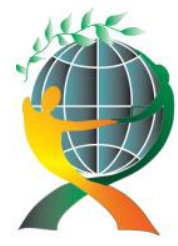

(online) $=$ ISSN $2285-3642$

ISSN-L = $2285-3642$

Journal of Economic Development, Environment and People

Volume 1, Issue 3, 2012

URL: http://jedep.spiruharet.ro

e-mail: office jedep@spiruharet.ro

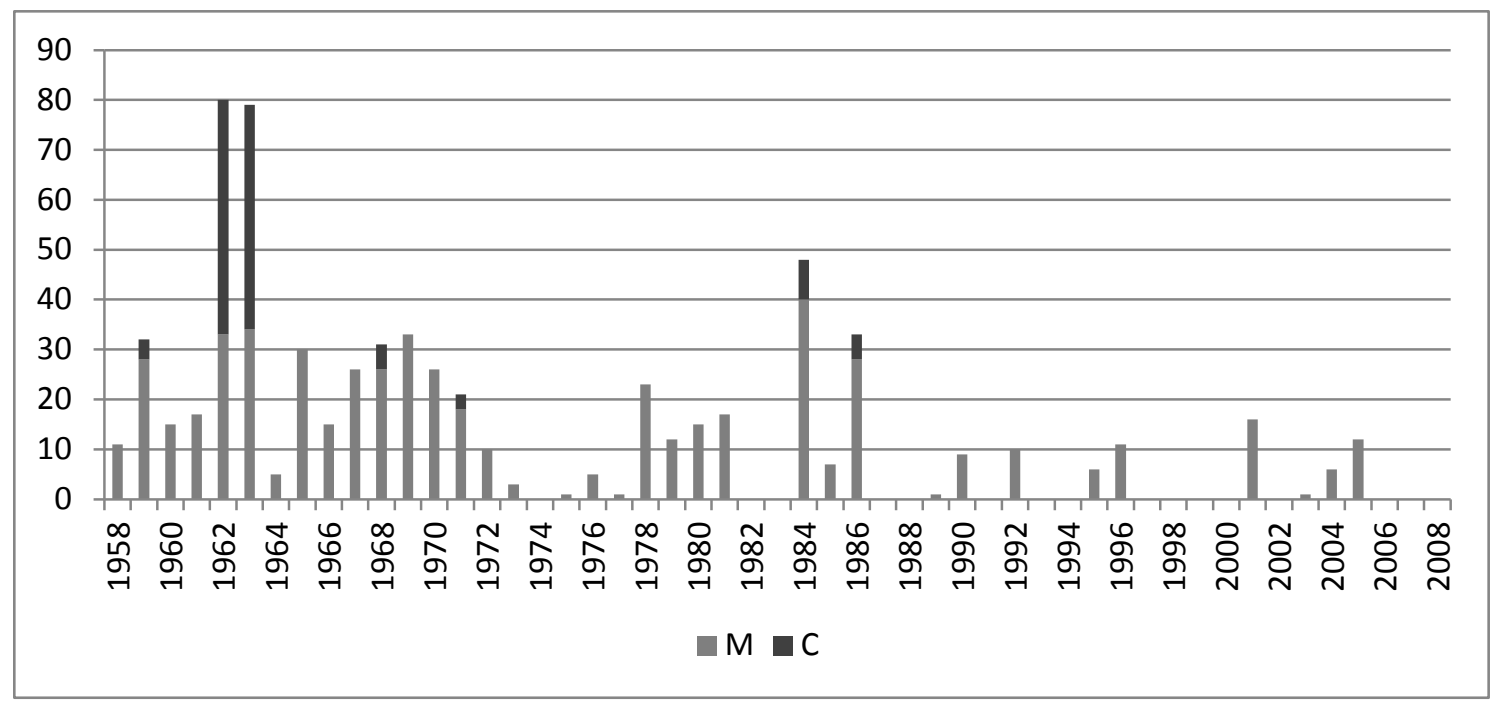

Fig. 8. Number of days with ice during winter ( $\mathrm{M}$ - ice in movement, $\mathrm{C}$ - frozen surface)

Table 3 shows characteristic values of probability for the whole period and for parts.

Table 4 shows mutual relationships among parameters from table 2, i.e. monitoring of parameter changes over the period.

Table 3. Characteristic values of probability for the whole period and for parts

\begin{tabular}{|l|c|c|c|c||}
\hline \multirow{3}{*}{ Probability } & \multicolumn{4}{|c|}{ period } \\
\cline { 2 - 5 } & $1958-1974$ & $1975-1991$ & $1992-2008$ & $1958-2008$ \\
\cline { 2 - 5 } & $\mathrm{t}_{1}$ & $\mathrm{t}_{2}$ & $\mathrm{t}_{3}$ & $\Sigma \mathrm{t}_{\mathrm{i}}$ \\
\hline $\mathrm{P}$ (per day) & 0.0699 & 0.0277 & 0.0100 & 0.0359 \\
\hline $\mathrm{P}$ (per year) & 0.0026 & 0.0019 & 0.0011 & 0.0019 \\
\hline
\end{tabular}

Table 4. Monitoring of parameter changes over the period

\begin{tabular}{|l|c|c|c|c|c|}
\hline \multirow{2}{*}{ Probability } & \multicolumn{5}{|c|}{$\mathrm{P}_{\mathrm{i}}$ ratio (\%) } \\
\cline { 2 - 6 } & $\mathrm{t}_{1} / \Sigma \mathrm{t}_{\mathrm{i}}$ & $\mathrm{t}_{2} / \Sigma \mathrm{t}_{\mathrm{i}}$ & $\mathrm{t}_{3} / \Sigma \mathrm{t}_{\mathrm{i}}$ & $\mathrm{t}_{3} / \mathrm{t}_{1}$ & $\mathrm{t}_{3} / \mathrm{t}_{2}$ \\
\hline $\mathrm{P}$ (per day) & 94.9 & -22.8 & -72.2 & -85.7 & -64.0 \\
\hline $\mathrm{P}$ (per year) & 37.1 & 2.9 & -40.0 & -56.3 & -41.7 \\
\hline
\end{tabular}




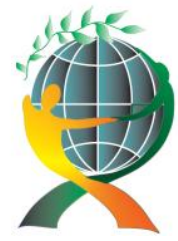

\author{
(online) $=$ ISSN $2285-3642$ \\ ISSN-L = 2285-3642 \\ Journal of Economic Development, Environment and People \\ Volume 1, Issue 3, 2012 \\ URL: http://jedep.spiruharet.ro \\ e-mail: office jedep@spiruharet.ro
}

\title{
3.1. Discussion
}

Based on the presented data, the following rules can be defined:

- average annual water levels tend to decrease, in other words, average depths of the waterway have a tendency of decrease

- significant decrease of average and extreme water levels ( $\min$ and max) for May, June, July and August

- increase of average and extreme water levels (min and max) in November, December and January

- tendency of probability decrease of occurrence of water levels lower than +80 and $+100 \mathrm{~cm}$ (significant decrease of occurrence of water levels lower than $+80 \mathrm{~cm}$ )

- standard deviation from average water level during the whole observed period, as well as for most months has the same value or has a tendency of slight decrease; except in August and September, where there is a tendency of increase

- significant decrease of the number of days with ice, as well as a significant decrease of probability of ice.

\section{Conclusion}

Risks are increasingly prevalent in complex transport and logistic chains. In addition to disruptions within each transport chain entity, the maze of interactions necessary for efficiently logistic operations can also be the origin for disruptions. Currently, there are no systematic methods to identify logistic risks in complex logistic chains. This is especially case in logistic chain where inland water transport presents one of the most crucial parts. Hence, in this paper, we propose a structured framework for characterizing risk in inland water transport chains. The first step of proposed risk management process is risk identification, and based on the proposed framework eight types of risks were identified in IWT chains: technology, infrastructure, political, economical, environmental, temporal, organizational, and legal. According to this, we analyze in detail river depth and ice occurrence as one of the infrastructure risks and crucial navigation characteristics of river.

The paper presented analysis of water level changes and occurrence of ice at one of the water meter stations in Serbia. The sequel to the paper requires further analysis of the given parameters at all water meter stations on navigable rivers in Serbia, according to the suggested method. In that way, a complete picture of the influence of climate changes on the parameters that influence the navigation on waterways of Serbia will be obtained. 


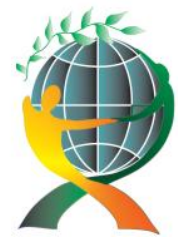

\author{
(online) $=$ ISSN $2285-3642$ \\ ISSN-L = 2285-3642 \\ Journal of Economic Development, Environment and People \\ Volume 1, Issue 3, 2012 \\ URL: http://jedep.spiruharet.ro \\ e-mail: office jedep@spiruharet.ro
}

Decrease of average annual water levels, with the decrease of probability of water levels lower than $+100 \mathrm{~cm}$, i.e. $+80 \mathrm{~cm}$, points to the fact that the period of favourable water levels for vessels of up to $2.5 \mathrm{~m}$ draught has been extended. However, additional analyses, which would confirm the assumption that the probability of occurrence of unfavourable water levels, i.e. depths, has increased for vessels with draught of over $3.0 \mathrm{~m}$ are necessary. It should be also mentioned that, during the observed period, along the Danube over the 30 dams were built (especially on the upper Danube), so that the changes of water levels were mostly conditioned by the dam regimes.

On the other hand, decrease of number of days with ice, i.e. probability of occurrence of ice, dramatically decreased during the observed period. Even though, globally, the described phenomenon is negative, from navigation point of view it has a positive effect. Namely, fewer days with ice, i.e. low probability of occurrence of ice, extends navigation period, i.e. the period of possible exploitation of boats.

Globally, climate changes increase risk and produce negative effects. From the aspect of navigation on mid-Danube, i.e. the part of Corridor VII that goes through Serbia, at the moment the share of positive effects is greater than the share of negative ones. Of course, constant and more detailed analyses are necessary, as well as connection between relevant climate and meteorological factors and discovery of mutual dependence and influence on hydrological phenomena.

The case study demonstrates the risk probability estimation of restricted river depth as a first part on risk assessment process. This work provides a good platform for further extensions of risk assessment and management process. In the next step we have to analyze possible consequence of restricted river depth and measures for managing and monitoring this kind of risk, and on that way we will have completed process of risk management.

\title{
5. Acknowledgements
}

This paper is a part of a research project entitled "Development and application of risk management models on corridors VII and X from the aspect of improvement of the transportation system of Serbia" (TR 36007) which is financed by The Ministry of science and technological development of the Republic of Serbia. 


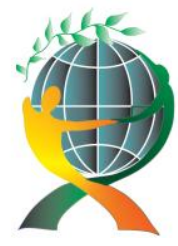

\author{
(online) $=$ ISSN $2285-3642$ \\ ISSN-L = 2285-3642 \\ Journal of Economic Development, Environment and People \\ Volume 1, Issue 3, 2012 \\ URL: http://jedep.spiruharet.ro \\ e-mail: office jedep@spiruharet.ro
}

\title{
6. References
}

[1] Arief A., Rajagopalan S., Iftekhar A. K. (2009). Supply Chain Risk Identification Using a HAZOP-Based Approach, AIChE Journal, Vol. 55, No. 6, pp. 1447.

[2] Doubrovsky M. (2005). Ukrainian and Russian waterways and the development of European transport corridors, European transport - International journal of Transport Economics, Engineering and Law, Year X, Number 30, pp. 14-36.

[3] White Paper: European transport policy for 2010: time to decide (2001). European Commission, Luxembourg, p. 41

[4] Jonkeren O., Rietveld P., Ommeren Jos. van (2007). Climate Change and Inland Waterway Transport: Welfare Effects of Low Water Levels on the river Rhine, Journal of Transport Economics and Policy, Volume 41, Number 3, September 2007 , pp. 387-411(25)

[5] Jonkeren O., Jourquin B., Rietveld P. (2009). Modal-split effects of climate change: The effect of low water levels on the competitive position of inland waterway transport in the river Rhine area, (article in press), Transportation Research Part A, 2009, doi:10.1016/j.tra.2009.01.004

[6] Kaplan S. (1997). The words of risk analysis, Risk Analysis, Vol. 17, No.4. 1997.

[7] Norrman A., Lindroth R. (2004). Categorization of Supply Chain Risk and Risk Management in C. Brindley (Ed.), Supply chain risk, Ashgate Publishing Limited, 2004

[8] Sulaiman O., Kader A.S.A., Saharuddin A.H. (2011). Collision Aversion Model for Inland Water Transportation: Cost Benefit Analysis Model, International Journal of Trade, Economics and Finance, Vol.2, No.1, 2010-023X

[9] Škiljaica V., Bačkalić T. (2002). Technical-exploitative characteristics of the Danube and its influence on the development of the river-sea traffic, 6th International Conference on Traffic Science, Portoroz, Slovenia.

[10] Škiljaica V., Bačkalić T. (2005). Navigation characteristics of the Danube and its influence on the main dimensions of the river-sea ships, Congress IMAM 2005, Lisbon, Portugal.

[11] Škiljaica V, Bačkalić T., Škiljaica I. (2009). Determining the possible size of draught of river-sea vessels on the lower section of the Danube, 13th International Congress International Maritime Association of Mediterranean, IMAM 2009 Congress, Istanbul, Turkey, 12-15 October 2009, pp 559-564. 